\title{
Severe theophylline poisoning: charcoal haemoperfusion or haemodialysis?
}

\author{
RM Higgins, S Hearing, DJA Goldsmith, B Keevil, MC Venning, P Ackrill
}

\begin{abstract}
Summary
Theophylline poisoning with a blood level of $183 \mathrm{mg} / \mathrm{l}$ in a 38-year-old man was treated with activated charcoal by mouth, but despite this the blood level of theophylline rose and there was circulatory collapse with rhabdomyolysis, acute renal failure and hyperthermia.

Treatment with charcoal haemoperfusion and simultaneous haemodialysis was given, followed by continuous arteriovenous haemodialysis (CAVHD). Mean extraction rates of theophylline were $26 \%$ during CAVHD, and $86 \%$ during combined dialysis and charcoal haemoperfusion. During combined treatment, the mean extraction rate of haemodialysis was $62 \%$, compared with $48 \%$ for charcoal haemoperfusion.

In summary, activated charcoal given by mouth may be unable to prevent a rise in blood levels and the development of complications after substantial theophylline overdose. If theophylline is to be removed from the blood, a combination of charcoal haemoperfusion and haemodialysis will give the best clearance, but haemodialysis alone may be effective.
\end{abstract}

Keywords: theophylline poisoning, charcoal haemoperfusion, haemodialysis

Renal Unit, Withington Hospital, Manchester M20 8LR, UK

RM Higgins

DJA Goldsmith

MC Venning

P Ackrill

Wythenshawe Hospital, Manchester, UK

Department of

Medicine

$S$ Hearing

Department of

Clinical Biochemistry

B Keevil

Correspondence to Dr RM Higgins, Renal Administration, Dulwich Hospital, East Dulwich Grove, London SE22 8PT, UK

Accepted 5 October 1994

\section{Introduction}

In theophylline poisoning, activated charcoal given by mouth has been shown to reduce the half-life of the drug, and has been recommended as first-line treatment. ${ }^{1-7}$ However, its efficacy has not been proven in massive overdose. Charcoal haemoperfusion has been recommended as the technique of choice if theophylline is to be removed. ${ }^{8-14}$ However, there are few data which compare charcoal haemoperfusion with modern dialysis techniques, using either biocompatible dialysis membranes or continuous dialysis.

We present a case of theophylline overdose treated with haemodialysis, charcoal haemoperfusion and continuous arteriovenous haemodialysis (CAVHD). Extraction rates and drug clearance rates were calculated for each of these techniques.

\section{Case report}

A 38-year-old man with mild asthma took approximately 100 tablets of theophylline slow release $250 \mathrm{mg}$ (Uniphyllin Continus, Napp Laboratories, Cambridge, UK). Six hours later he presented to hospital with a sinus tachycardia of 125 beats/min and plasma potassium level of $2.8 \mathrm{mmol} / 1$.

Ten hours after admission he developed a broad complex tachycardia with cardiac arrest and fits. Sinus rhythm was restored by cardioversion. The blood level of theophylline was $183 \mathrm{mg} / \mathrm{l}$. Activated charcoal was given, at a dose of $200 \mathrm{~g}$ followed by $50 \mathrm{~g}$ every two hours via a nasogastric tube.

Seventeen hours after admission he developed continual fitting with a supraventricular tachycardia and respiratory arrest. He was intubated and ventilated. He had profound shock, and intravenous adrenaline and noradrenaline were administered. He was oliguric, and had a core temperature of $41.8^{\circ} \mathrm{C}$. The blood level of theophylline had risen to $192 \mathrm{mg} / \mathrm{l}$, despite the continued administration of activated charcoal (figure).

Charcoal haemoperfusion was commenced 25 hours after overdose. Bilateral femoral venous cannulae were inserted and blood passed sequentially through a charcoal column (Gambro Adsorba 300c), and an artificial kidney (Fresenius F6) with bicarbonate buffered dialysate at a flow rate of $500 \mathrm{ml} / \mathrm{min}$. Blood flow was $250 \mathrm{ml} / \mathrm{min}$, and hydrocortisone $100 \mathrm{mg}$ and chlorpheniramine $4 \mathrm{mg}$ were

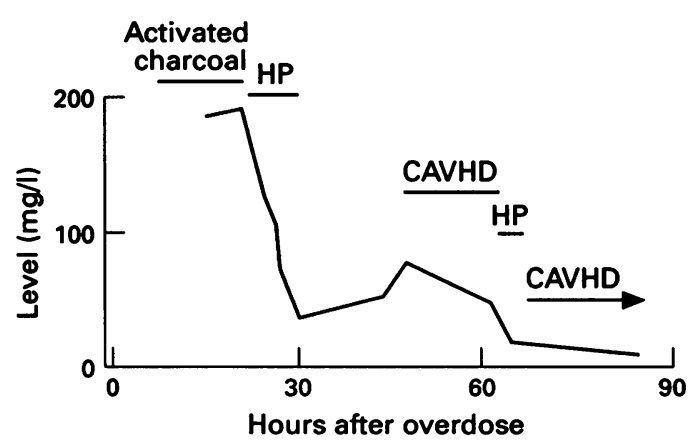

Figure Time course of theophylline levels and treatment given. HP, charcoal haemoperfusion combined with haemodialysis; CAVHD, continuous arteriovenous haemodialysis 
given intravenously at the start of this treatment.

Treatment was given for four hours (figure). The blood level of theophylline fell to $36 \mathrm{mg} / \mathrm{l}$, and the pulse rate from 170 to 128 beats $/ \mathrm{min}$. The following morning the blood level rose to $49 \mathrm{mg} / \mathrm{l}$, and CAVHD was started, using Dianel 6.1 dialysate at a flow rate of $1 \mathrm{l} / \mathrm{h}$. After $40 \mathrm{~h}$ of CAVHD the blood level of theophylline had fallen from $78 \mathrm{mg} / 1$ to $49 \mathrm{mg} / \mathrm{l}$, but as there was persistent tachycardia and the drug was not being removed quickly, a second treatment with charcoal haemoperfusion was given. Thereafter the blood level was less than $10 \mathrm{mg} / \mathrm{l}$.

There were no dysrhythmias after the start of the first dialysis session, but the patient remained oliguric for two weeks. The creatinine kinase level was elevated at $31000 \mathrm{iu} / \mathbf{l}$, so that rhabdomyolysis was considered to be a major contributory factor in the development of acute renal failure. Compartment syndrome developed in the calves, and this was treated with bilateral fasciotomies.

Despite the eventual recovery of renal function, he had sustained irreversible brain damage and was unable to sustain spontaneous ventilation. It was thought that he may have sustained cerebral hypoxia either during resuscitation from cardiac arrest, or while he was profoundly shocked and receiving large doses of intravenous noradrenaline. He died three weeks after taking the overdose.

\section{AMINOPHYLLINE CLEARANCES}

Simultaneous blood samples were taken from the afferent and efferent blood lines about both the charcoal column and artificial kidney, and also from the radial artery. Samples were also taken across the artificial kidney during CAVHD. Theophylline was analysed using the Technicon theophylline assay (Bayer Diagnostics). The assay is sensitive down to $2.5 \mathrm{mg} / 1$ and the between-assay variability at a level of $30 \mathrm{mg} / \mathrm{l}$ is a standard deviation of $1.6 \mathrm{mg} / \mathrm{l}$ and a coefficient of variability of 5.2. Extraction rate and clearance were calculated according to the formulae:

$$
\begin{gathered}
\text { Extraction rate }=\frac{(\text { afferent level }- \text { efferent level })}{\text { afferent level }} \times 100 \% \\
\text { Clearance }=\text { extraction rate } \times \text { blood flow }(\mathrm{ml} / \mathrm{min}) .
\end{gathered}
$$

Four sets of blood samples for clearance measurements were taken during each session of charcoal haemoperfusion and haemodialysis (table 1), and the mean extraction rates and clearances for the combined treatment as well as the dialysis and haemoperfusion components are shown in table 2 .

Table 1 also shows the blood levels of theophylline during the first session of dialysis, when simultaneous blood samples were taken from the radial artery and femoral venous cannula. Despite the tendency for recirculation of blood from the efferent dialysis line to dilute blood entering the dialysis circuit from the femoral vein, the theophylline level was always lower in the radial artery than in the afferent dialysis line. This suggests release of theophylline into venous blood coming from the legs.
Table 1 Theophylline levels during char-

\begin{tabular}{|c|c|c|c|c|}
\hline Time & $\begin{array}{l}\text { Radial } \\
\text { artery }\end{array}$ & $\begin{array}{l}\text { Dialysis } \\
\text { inlet }\end{array}$ & $\begin{array}{l}\text { Distal to } \\
H P\end{array}$ & $\begin{array}{l}\text { Distal to } \\
H D\end{array}$ \\
\hline \multicolumn{5}{|c|}{ 1st $H P$ and $H D$ session } \\
\hline $1 \mathrm{~h}$ & 120.0 & 135.0 & 126.0 & 8.2 \\
\hline $2 \mathrm{~h}$ & 92.0 & 107.0 & 41.3 & 13.8 \\
\hline $3 \mathrm{~h}$ & 34.6 & 71.0 & 37.7 & 13.1 \\
\hline $4 \mathrm{~h}$ & ND & 53.0 & 22.3 & ND \\
\hline$C A V H D$ & ND & 78.0 & - & 57.5 \\
\hline \multicolumn{5}{|c|}{ 2nd $H P$ and $H D$ session } \\
\hline $10 \mathrm{~min}$ & ND & 36.2 & 1.0 & 0.9 \\
\hline $1 \mathrm{~h}$ & ND & 27.9 & 5.9 & 3.3 \\
\hline $2 \mathrm{~h}$ & 22.7 & ND & 11.7 & 4.5 \\
\hline $3 \mathrm{~h}$ & ND & 14.7 & 10.1 & 3.2 \\
\hline
\end{tabular}
coal haemoperfusion and dialysis

The theophylline level in the CAVHD dialysate was also measured, simultaneously with the other two samples, and was $58.2 \mathrm{mg} / \mathrm{l}$, indicating dialysis equilibrium with the blood. CAVHD, continuous arteriovenous haemodialysis; HD, haemodialysis; HP, charcoal haemoperfusion.

Table 2 Extraction rate, clearance and halflife of theophylline

\begin{tabular}{llll}
\hline $\begin{array}{l}\text { Treatment } \\
\text { modality }\end{array}$ & $\begin{array}{l}\text { Extraction } \\
(\%)\end{array}$ & $\begin{array}{l}\text { Clearance } \\
(\mathrm{ml} / \mathrm{min})\end{array}$ & $\begin{array}{l}\text { Half-life } \\
(\mathrm{h})\end{array}$ \\
\hline Oral charcoal & - & - & $\begin{array}{l}\text { (rising } \\
\text { level) }\end{array}$ \\
CAVHD & 26 & - & 15 \\
HD & 62 & 156 & - \\
HP & 48 & 120 & - \\
HP + HD & 86 & 215 & 2.5 \\
\hline
\end{tabular}

CAVHD, continuous arteriovenous haemodialysis; HD, haemodialysis; HP, charcoal haemoperfusion.

\section{Discussion}

This patient with severe theophylline overdose manifested the expected features of poisoning with blood levels of over $175 \mathrm{mg} / 1$ (see box). ${ }^{1,2,15}$

In this case the administration of activated charcoal by mouth was ineffective in preventing a rise in blood levels. Activated charcoal has been shown to reduce the half-life of theophylline in cases with blood levels of less than $60 \mathrm{mg} / \mathrm{l}^{5-7}$ However, it is possible that in substantial overdose the amount of theophylline available for binding to charcoal may exceed its absorptive capacity. Therefore when activated charcoal is given by mouth, there should be measurements of theophylline blood levels.

In our case theophylline was removed from the blood by dialysis combined with charcoal haemoperfusion. Although most previous

\begin{tabular}{|ll|}
\hline $\begin{array}{l}\text { Features of severe theophylline } \\
\text { poisoning }\end{array}$ \\
\hline \begin{tabular}{ll} 
- hypokalaemia & $\bullet$ hypotension \\
- cardiac dysrhythmias & : hyperthermia \\
- fits & rhabdomyolysis \\
\hline
\end{tabular} \\
\hline
\end{tabular}


reports have suggested that charcoal haemoperfusion is superior to haemodialysis in theophylline overdose, the published data were obtained several years ago. In some cases dialysis was performed using flat-plate artificial kidneys and low blood flow rates. ${ }^{8,16}$ Our data, as well as that of Krishna et al, ${ }^{17}$ suggest that, if charcoal haemoperfusion is not readily available, haemodialysis alone may be used. The duration of treatment may need to be extended if a charcoal column is not used, but we would recommend that serial blood levels should be measured whichever dialysis technique is used

Are continuous methods of providing renal replacement therapy useful in theophylline poisoning? In recent years a number of new techniques have been introduced, using either arteriovenous blood flow, or pumped venovenous blood flow. This may be combined with either continuous haemodialysis, or haemofiltration and replacement with an electrolyte solution. Theophylline clearance during continuous dialysis has not previously been reported. ${ }^{14}$

CAVHD achieved an extraction rate of only $26 \%$ in our case. The clearance could not be calculated, because there were no measurements of blood flow through the CAVHD circuit. However, the half-life of theophylline during CAVHD was 15 hours, much longer than that during combined charcoal haemoperfusion and haemodialysis. Thus continuous dialysis methods are not likely to be useful in theophylline overdose because of relatively low flow rates of both blood and dialysate.

There was a significant rebound in blood levels after the first treatment with charcoal haemoperfusion, from $36 \mathrm{mg} / 1$ to $78 \mathrm{mg} / 1$. This phenomenon has previously been attributed to delayed absorption of theophylline from the gastrointestinal tract. ${ }^{15,18}$ In our case, there

1 Gaudreault P, Guay J. Theophylline poisoning: pharmacological considerations and clinical management. Med Toxicol 1986; 1: 169-91.

2 Tsiu SI, Self TH, Burns R. Theophylline toxicity: update. Ann Allergy 1990; 64: 241-57.

3 Editorial. Self-poisoning with theophylline. Lancet 1985; 146-7.

4 Vale JA, Proudfoot AT. How useful is activated charcoal? BMF 1993; 306: 78-9.

5 Mahutte R, True RJ, Michials TM, Berman JM, Light RW. Decreased serum theophylline clearance with orally administered activated charcoal. Am Rev Respir Dis 1983, 128: $820-2$.

6 Radmonski L, Park GD, Goldberg MJ, Spector R, Johnson GF, Quee CK. Model for theophylline overdose treatment with oral activated charcoal. Clin Pharmacol Ther 1984; 35: 402-8.

7 Ohning BL, Reed MD, Blumer JL. Continuous nasogastric administration of activated charcoal for the treatment of theophylline intoxication. Pediatr Pharmacol 1986; 5: theoph

8 Levy G, Gibson TP, Whitman W, Procknal J. Hemodialysis clearance of theophylline. $\mathcal{F} A M A$ 1977; 237: 1466-7.

9 Ehlers SM, Zaske DE, Sawchuk RJ. Massive theophylline overdose; rapid elimination by charcoal haemoperfusion. f $A M A$ 1978; 240: 474-5.

10 Russo ME. Management of theophylline intoxication with charcoal-column haemoperfusion. N Engl f Med 1979; 300 $24-6$.
Severe theophylline poisoning

- oral activated charcoal may not prevent a rise in blood level

- charcoal haemoperfusion is the treatment of choice

- if this is not available, haemodialysis alone is of benefit

were consistently higher theophylline levels in the femoral vein than in the radial artery (table 1). This suggests the release of drug from the leg. It is known that theophylline is distributed in the body in a two-compartment manner. ${ }^{1,2}$ One of these compartments is the circulating blood, but if a significant part of the second compartment were muscle, then the drug could be released after fitting and muscle damage. Rebound in blood levels after an initial fall have previously been reported in association with fitting and severe muscle damage in the calves requiring fasciotomy. ${ }^{15}$

In conclusion, we have presented a case of severe theophylline overdose, in whom treatment with oral activated charcoal was not sufficient to prevent a rise in blood levels. If charcoal haemoperfusion is not available, haemodialysis alone may be an effective method for rapid theophylline removal. However, the extraction rate and half-life of theophylline during continuous arteriovenous haemofiltration did not provide rapid therapeutic benefit. If active elimination techniques are to be used in cases of massive theophylline overdose, they also need to be instituted early and not, as here, 25 hours afterwards, when cardiac arrest had already occurred and irreversible brain damage had been sustained.

11 Jeffreys DB, Raper SM, Helliwell M, Berry DJ, Crome P Haemoperfusion for theophylline overdose. BMF 1980; 281: 1167.

12 Park GD, Spector R, Roberts RJ, et al. Use of hemoperfusion for treatment of theophylline intoxication. $A m \mathcal{F ~ M e d}$ 1983; 74: 961-6.

13 Greenberg A, Piraino BH, Kroboth PD, Weiss J. Severe theophylline toxicity; role of conservative measures, antiarrhythmic agents, and charcoal haemoperfusion. $A m \mathcal{F ~ M e d}$ 1984; 76: 854-60.

14 Benowitz NL, Toffelmire EB. The use of hemodialysis and hemoperfusion in the treatment of theophylline perfusion. Semin Dialysis 1993; 6: 243-52.

15 Lloyd DM, Payne SPK, Tomson CRV, Barnes MR, Allen MJ. Acute compartment syndrome secondary to theophylline overdose. Lancet 1990; 336: 312.

16 Lee C-SC, Peterson JC, Marbury TC. Comparative pharmacokinetics of theophylline in peritoneal dialysis and macokinetics of theophylline in peritoneal dialys

17 Krishna GG, Zahrowski JJ, Nissenson AR. Hemodialysis for theophylline overdose. Dialysis Transplant 1983; 12: 40-2.

18 Connell JMC, McGeachie JF, Knepil J, Thomson A, Junor B. Self-poisoning with sustained-release aminophylline: secondary rise in serum theophylline concentration after charcoal haemoperfusion. BMf 1982; 285: 943. 